\title{
Production of $\alpha$-amylase using new strain of Bacillus polymyxa isolated from sweet potato
}

\author{
Nagib Elmarzugi ${ }^{1,2,6^{*}}$, Hesham A. El Enshasy ${ }^{1,3}$, Elsayed A. Elsayed ${ }^{4,5}$, Aref \\ Taleb $^{2}$, Ezzedin Keleb ${ }^{2}$, Suhaila Naji ${ }^{6}$, Otman Elrmithi ${ }^{6}$, Nor Zalina Othman ${ }^{1}$ \\ ${ }^{1}$ Institute of Bioproduct Development (IBD), Universiti Teknologi Malaysia (UTM), Skudai, Johor, Malaysia. \\ ${ }^{2}$ Faculty of Pharmacy, Tripoli University, Tripoli, Libya \\ ${ }^{3}$ City of Scientific Research and Technology Applications, New Burg Al Arab, Alexandria, Egypt. \\ ${ }^{4}$ Bioproducts Research Chair, Zoology Department, Faculty of Science, King Saud University (KSU), \\ Kingdom of Saudi Arabia. \\ ${ }^{5}$ Natural and Microbial Product Department, National Research Centre, Dokki, Cairo, Egypt. \\ ${ }^{6}$ Biotechnology Research Centre, Tripoli, Libya
}

\begin{abstract}
In this study, a new amylase producer strain was isolated from sweet potato tuber. This strain was able to grow at $37^{\circ} \mathrm{C}$ and produce $\alpha$-amylase in high quantity compared to other standard strain cultures. In the first part, cultivation in shake flask in standard medium was carried out to give complete information about the growth and production kinetics of this strain. The results clearly demonstrate that the isolated strain is able to production $\alpha$-amylase in submerged culture with concentration up to $2050 \mu k a t / L$ after $20 \mathrm{~h}$ cultivation. Furthermore, medium optimization was carried out by changing the starch concentration and cell cultivation in medium of mixed carbon source (composed of starch and glucose of ratio $15: 5 \mathrm{~g} / \mathrm{g}$ ) to enhance the production process and to increase the growth rate. The volumetric and specific $\alpha$-amylase production in this optimized medium were $4550 \mu \mathrm{kat} / \mathrm{L}$ and $1060 \mu \mathrm{kat} / \mathrm{g}$, respectively. Further improvement in enzyme production process was achieved by scaling up the process from shake flask to 3-L stirred tank bioreactor under non-oxygen limiting condition. The maximal volumetric and specific $\alpha$-amylase productions in bioreactor batch culture were $5210 \mu \mathrm{kat} / \mathrm{L}$ and $1095 \mu \mathrm{kat} / \mathrm{g}$, respectively, after only $14 \mathrm{~h}$ cultivation.
\end{abstract}

Keywords - $\alpha$-amylase, Bacillus polymyxus, bioprocess optimization, batch cultivation

\section{Introduction}

Starch is the most abundant storage carbohydrate in plant kingdom and the second feed stock of plant material next to cellulose. Thus, it is the major energy storage material in many crops such as wheat, maize, rice, cassava and potato [1]. Starch is glucose polymer of different chain molecular weight and morphology (chain length and branching) depending on its origin. Starch needs to be hydrolyzed first to monosaccharide (glucose) or oligosaccharide (maltose) to be easily metabolized. Different classes of starch degrading enzymes are produced naturally by different types of plant, animal and microorganisms. Among different starch degrading enzymes, the most industrially important amylases are: $\alpha$-amylase (EC 3.2.1.1.), $\beta$-amylase (EC 3.2.1.2) and glucoamylase (EC 3.2.1.3). These enzymes are require individually or in combination during industrial application. The production process of these enzymes involve mainly strains belong to bacteria (especially strains belong to Bacilli such as B. amyloliquefaciens and B. cereus), and fungi (mainly belong to Aspergillus group such as A. oryzae and A. awamori [2-5].

$\alpha$-amylase (1,4- $\alpha$-D-glucan-glucanhydrolase, EC 3.2.1.1; CAS \# 9000-90-2) is the most industrially important enzyme. This biocatalyst is a classical calcium containing protein and belongs to endo-amylases family and catalyzes the cleavage of $\alpha$-D-(1-4) glycosidic bonds in starch and related carbohydrates with retention of the $\alpha$-anomeric configuration in the products [6]. Therefore, in addition to its latest application in biorefinery and biofuel production, this enzyme finds many applications in different sectors of wellness industries including: starch liquefaction, food industries, pharmaceutical and drug industries [7-9]. Large scale industrial production of this enzyme is carried out mainly in submerged culture using different types of microorganisms. However, most of industries preferred using bacterial strains belongs to Bacillus strain because of the long history of this type of organisms in industry for the production of different hydrolytic enzymes [10]. The most widely used Bacillus strains for amylase production are B. subtilis; B. amyloliquefaciens; $B$. licheniformis [11-13]. However, most of industrial strains of high productivity grew at $30{ }^{\circ} \mathrm{C}$. Thus, cooling is required during the cultivation process when cells cultivated in large scale submerged culture especially in subtropical and tropical countries. The aim of this work was to develop a cultivation strategy for amylase production with short cultivation time by applying a new $\alpha$-amylase producer strain which is able to grow and produce enzyme effectively at $37^{\circ} \mathrm{C}$. Applying mesophilic microbes of high ability to grow and produce 
enzyme at relatively high temperature will reduce the production cost. This based on the fact that the cooling water cost have high share in the bioreactor operation cost especially in sub-tropical and tropical countries.

\section{Materials and Methods \\ Isolation and selection of $\alpha$-amylase producer strain}

Sweet potato tuber sample was obtained from local market of Tripoli, Libya. 10 gm of decayed part of the tuber was taken in $100 \mathrm{ml}$ water. The sample was then diluted by using serial dilution method and plated on selective agar plate to isolate the most effective enzyme producer strain according to Samie et al. [14]. Agar medium was composed of (g/L): soluble starch 1.0; $\mathrm{KH}_{2} \mathrm{PO}_{4} 1.0 ; \mathrm{CaCl}_{2} .2 \mathrm{H}_{2} \mathrm{O} 0.05 ;\left(\mathrm{NH}_{4}\right)_{2} \mathrm{SO}_{4}$ 2.0; Tryptone 2.0; $\mathrm{MgSO}_{4} .7 \mathrm{H}_{2} \mathrm{O} 0.05 ; \mathrm{Na}_{2} \mathrm{HPO}_{4} .2 \mathrm{H}_{2} \mathrm{O} 3.13 ;$ Agar 20. The medium was adjusted to $\mathrm{pH} 7.0$ before sterilization. The amylase producer strain was isolated by flooding the agar plates with $1 \%(\mathrm{w} / \mathrm{v})$ iodine solution. The most effective isolate was selected, subcultured and further identified.

\section{Identification of the $\alpha$-amylase producer strain}

Morphological and biochemical methods were carried out to identify the enzyme producer strain. The initial morphological observation shows that the strain is rod-shaped, G+ve and endo spore former bacteria. Therefore, biochemical identification was carried out using standard API biochemical test for identification of Bacilli [15] (BioMérieux Co, France). The data obtained from API tests were used for strain identification using API software. The results are fully matched with the morphological and biochemical feature of Bacillus polymyxa.

\section{Strain preservation and inoculum preparation}

The isolated strain was preserved in frozen in $50 \%$ glycerol solution $(\mathrm{v} / \mathrm{v})$ at $-80{ }^{\circ} \mathrm{C}$. Before use, the cells were activated twice in LB agar medium of the following composition $(\mathrm{g} / \mathrm{L})$ : beef extract 5 , peptone 10 , yeast extract $5, \mathrm{NaCl} 5$, and agar $20(\mathrm{pH} 7)$. After $24 \mathrm{~h}$ day cultivation, the arisen colonies were used to inoculate 250-ml Elrlenmeyer flask (of $50 \mathrm{ml}$ working volume) containing LB broth. The inoculated flasks were incubated on rotary shaker at $37^{\circ} \mathrm{C}$ and $200 \mathrm{rpm}$ for $24 \mathrm{~h}$.

\section{Fermentation medium and cultivation conditions}

The medium used for enzyme production had the following composition $(\mathrm{g} / \mathrm{L})$ : $\left(\mathrm{NH}_{4}\right)_{3} \mathrm{PO}_{4}, 5$; Yeast extract $1, \mathrm{~K}_{2} \mathrm{HPO}_{4} 1, \mathrm{MgSO}_{4} .7 \mathrm{H}_{2} \mathrm{O} 0.5$; Sodium citrate $0.1 ; \mathrm{CaCl}_{2} 0.1 ; \mathrm{FeSO}_{4} .7 \mathrm{H}_{2} \mathrm{O} 0.1 ; \mathrm{MnSO}_{4} . \mathrm{H}_{2} \mathrm{O} 0.1$ and soluble starch 10 [12]. Cultivations were carried out in shake flask and in bioreactor at $37^{\circ} \mathrm{C}$. In case of shake flask, $250 \mathrm{ml}$ Erlenmeyer flask of working volume of $50 \mathrm{ml}$ was used in this study. The inoculum was in form of $4 \mathrm{ml}$ of cell suspension (of $1 \mathrm{OD}$ at $600 \mathrm{~nm}$ ) obtained from previously cultivated cells in LB medium for $24 \mathrm{~h}$. The inoculated flasks were incubated on rotary shaker at $200 \mathrm{rpm}$ and $37^{\circ} \mathrm{C}$ (Innova 44, New Brunswick Scientific, NJ, USA). Cultivations in bioreactor scale were carried out in 3-L stirred tank bioreactor (Bioflo III, New Brunswick Scientific, NJ, USA) with a working volume of 2L. Agitation was performed by two 4-bladded Rushton turbine impellers $\left(\mathrm{d}_{\mathrm{i}}\right.$, impeller diameter $\left.=65 \mathrm{~mm} ; \mathrm{d}_{\mathrm{t}(\text { tank diameter })}=135 \mathrm{~mm}, \mathrm{~d}_{\mathrm{i}} \mathrm{d}_{\mathrm{t}}=0.48\right)$ at $400 \mathrm{rpm}$. Aeration was performed by filtered sterile air at the rate of $1 \mathrm{v} / \mathrm{v} / \mathrm{min}$. $\mathrm{pH}$ values and Dissolved oxygen concentrations was measured during cultivation using on-line electrodes attached to the bioreactor controller (Mettler Toledo, Switzerland). Foam was suppressed $b$ the addition of silicon antifoam reagent (Antifoam A, Sigma, USA).

\section{Analytical methods}

Samples were taken at different time intervals in form of $10 \mathrm{ml}$ and $50 \mathrm{ml}$ in case of bioreactor and shake flasks, respectively. After sampling, the optical density of culture was determined immediately by using spectrophotometer (Novaspec II, Pharmacia Biotech, Sweden) at $\mathrm{OD}_{600}$. Samples were centrifuged at $6000 \mathrm{RPM}$ and the cells were washed/centrifuged twice before drying in an oven at $110^{\circ} \mathrm{C}$ for $24 \mathrm{~h}$. One $\mathrm{OD}_{600}$ unit was equivalent to $0.29 \mathrm{~g}$ (cell dry weight/L). The supernatant was frozen at $-20^{\circ} \mathrm{C}$ and stored for further analysis. Determination of $\alpha$-amylase activity was carried out according to the method of Bernfeld and modified by Stellmach [16]. In this method, $0.5 \mathrm{ml}$ of sample, previously diluted in $0.05 \mathrm{M}$ acetate buffer of $\mathrm{pH} 4.9$, was incubated for $3 \mathrm{~min}$ at $25^{\circ} \mathrm{C}$ with $0.5 \mathrm{ml}$ of $1 \%$ soluble starch solution. The reaction was terminated by addition of $1 \mathrm{ml}$ of dinitrosalicylic acid color developing agent. The sample was then heated for $5 \mathrm{~min}$ in boiling water bath and cooled immediately in ice bath to stop the color developing reaction. After addition of $10 \mathrm{ml}$ of distilled water, the sample optical density was determined at $540 \mathrm{~nm}$. The enzyme activity is expressed in Katal unit which defined as the amount of activity that produces one mole of reducing group per second [17]. 


\section{Isolation and Identification of the bacterial strain}

\section{Results and Discussion}

Ten $g$ of decayed part of sweet potato tubers were taken and washed with sterile saline solution and further homogenized using food mixer with $20 \mathrm{ml}$ of double distilled water. The obtained homogenized mixture was diluted up to $1 \times 10^{-8}$ from each sample $1 \mathrm{ml}$ was taken and plated over starch selective medium as described in materials and methods part and incubated at $37{ }^{\circ} \mathrm{C}$ for rapid isolation of amylase producers. The arisen colonies were isolated and tested for their potency for amylase production using agar plate method. The highest producer strain was identified using morphological, biochemical and API identification kits, API 20E and API CHB50 (Biomerieux, France). The tests included: Gram staining, incubation temperature, anaerobic growth, Voges-Proskauer and methyl red test, catalase production, growth in $\mathrm{NaCl}$ solution, growth at $\mathrm{pH} 5$ and 7 , fermentation of carbohydrate, starch hydrolysis, utilization of citrate, formation of indole, formation of dihydroxyacetone, deamination of phenylalanine, casein hydrolysis, tyrosine degradation, getalin hydrolysis, egg yolk lecithinase, growth in the presence of lysozyme) according to the standard method of bacilli identification $[18,19]$. Identification of the bacterial strain was carried out by using API-web program of the manufacturer. The obtained results clearly demonstrate that this strain excellent identification with high percentage matching to Bacillus polymyxa.

\section{Kinetics of cell growth and $\alpha$-amylase production in standard fermentation medium}

For better understanding of the kinetics of cell growth and enzyme production of the newly isolated strain, cultivations were carried out in shake flask to evaluate the enzyme production process. As shown in fig. 1, after a lag phase of about 4 hours, cells grew exponentially with rate of $0.123 \mathrm{~g} / \mathrm{L} / \mathrm{h}$ and reached maximal biomass of about $2 \mathrm{~g} / \mathrm{L}$ after $20 \mathrm{~h}$ cultivation. In parallel to cell growth, cells produced $\alpha$-amylase in culture continuously mainly after lag phase of about 6 hours and accumulated in culture with almost constant rate of $140 \mu \mathrm{kat} / \mathrm{L} / \mathrm{h}$ reaching a maximal enzyme concentration of $2050 \mu \mathrm{kat} / \mathrm{L}$. On the other hand, for better understanding of the cell performance for enzyme production, the yield coefficient $Y_{\mathrm{P} / \mathrm{X}}$ which give the value of specific enzyme production per gram of biomass was also calculated. As shown in figure 1, the maximal value of yield coefficient of about $1200 \mu \mathrm{kat} / \mathrm{g}$ was obtained after $16 \mathrm{~h}$ cultivation and kept more or less constant for the production time. This clearly indicate that the cell performance for enzyme production was changed during cell cultivation and cells need time to reach maximal cell performance for enzyme production which is almost close to the late exponential growth phase. However, the amount of enzyme produced in this culture was higher than other published standard bacillus strain such as B. amyloliquefaciens [11]. The phenomena of parallel relation between cell growth and $\alpha$-amylase production profile was also observed in other strains such as in case of B. licheniformis [20], B. amyloliquefaciens [12] and Micrococcus varians [21].

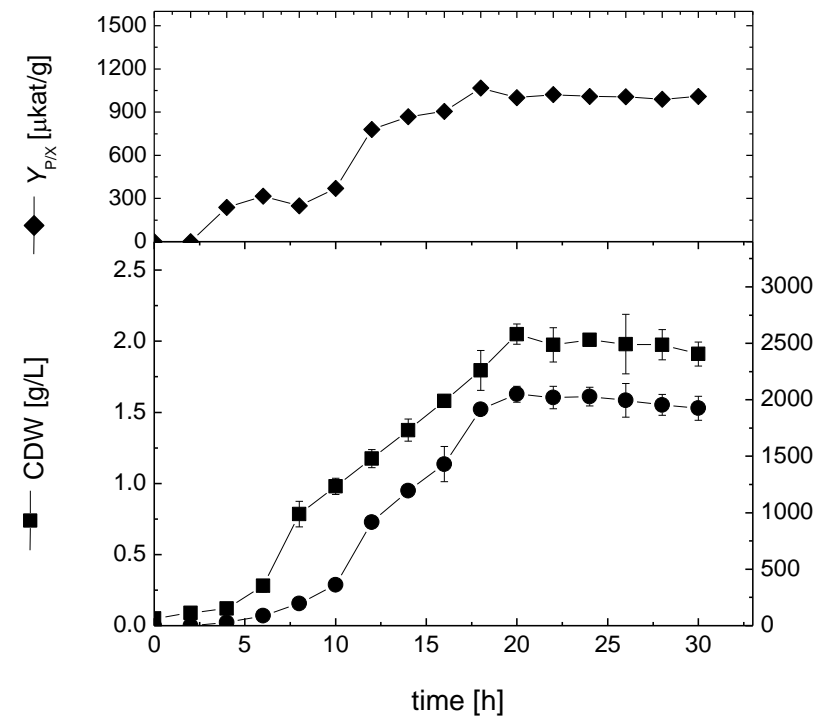

Figure 1. Time profiles of cell growth and $\alpha$-amylase production during submerged fermentation of B. polymyxa. (Values are mean \pm standard deviation, $n=3$ ) 


\section{Different starch concentrations}

In this experiment, further attempt was done to increase the volumetric production of $\alpha$-amylase using the newly isolated strain. Thus, cultivations were carried out in shake flask in media of different starch concentrations ranged between $0-40 \mathrm{~g} / \mathrm{L}$ and data taken after $20 \mathrm{~h}$ cultivation based on the results of the previous experiment. Fig. 2 demonstrates the results of biomass, volumetric and specific $\alpha$-amylase production. As shown, the maximal biomass of $3.55 \mathrm{~g} / \mathrm{L}$ was obtained in $30 \mathrm{~g} / \mathrm{L}$ starch culture and further increase in starch concentration resulted in reduction in biomass. For $\alpha$-amylase production, the maximal volumetric and specific yield of about $3500 \mu \mathrm{kat} / \mathrm{L}$ and $1046 \mu \mathrm{kat} / \mathrm{g}$, respectively, were obtained in culture supplemented with only 20 $\mathrm{g} / \mathrm{L}$ starch.

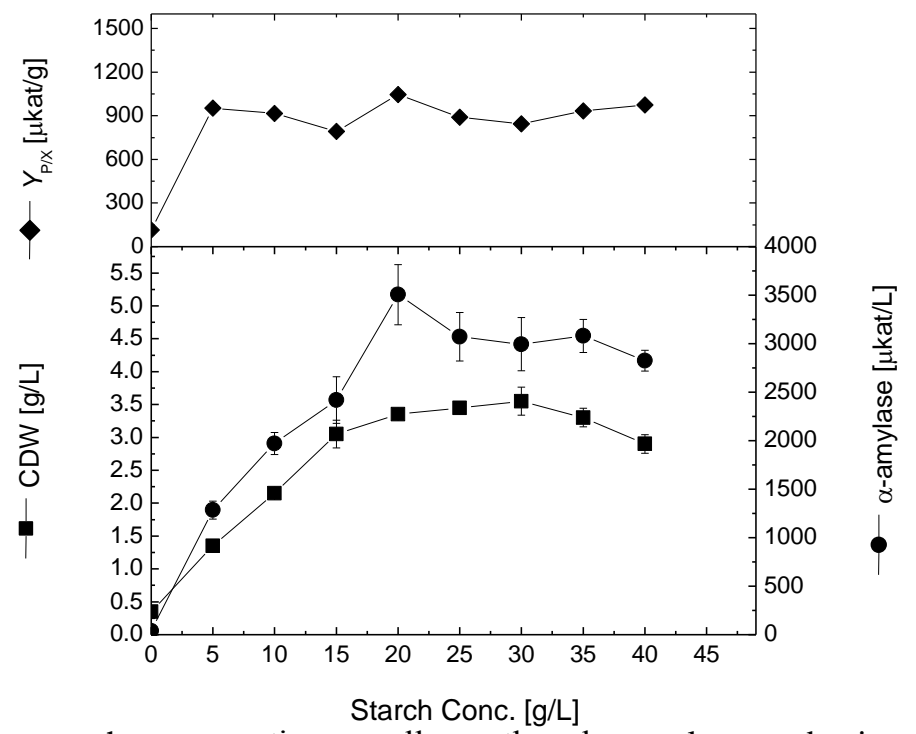

Figure 2. Effect of different starch concentration on cell growth and $\alpha$-amylase production during submerged fermentation of B. polymyxa. Data were taken after $20 \mathrm{~h}$ cultivation (Values are mean \pm standard deviation, $n=3$ )

On the other hand, the values of specific $\alpha$-amylase production in all starch supplemented culture were ranged between 850 to $1050 \mu \mathrm{kat} / \mathrm{g}$. Thus, we can conclude that the optimal starch concentration for $\alpha$-amylase production in this medium is $20 \mathrm{~g} / \mathrm{L}$.

\section{Effect of different starch/glucose ratio}

Based on the growth curve (fig. 1) of this study, after inoculation of cells into the production medium, cells entered lag-phase of about 4 hours as adaptation phase prior exponential cell growth. This phase is due to the big different between the composition of vegetative growth medium and fermentation medium. In the later medium, carbon source is mainly starch (with small fraction of carbon source in yeast extract). Therefore, cells need to produce starch degrading enzyme first to degrade starch to C-6 monomor (glucose) or disaccharide maltose for cell utilization. To reduce this problem of long lag phase, cells were cultivated in different media of range of (starch:glucose) ratio to investigate the effect of (starch:glucose) mixture when applied as carbon source on cell growth and $\alpha$-amylase production. As shown in figure 3 , the maximal biomass of about $7 \mathrm{~g} / \mathrm{L}$ was obtained in pure glucose supplemented culture. This value is about two fold higher compared to starch supplemented culture. On the other hand, the maximal volumetric and specific $\alpha$-amylase production of about $4580 \mu \mathrm{kat} / \mathrm{L}$ and $1077 \mu \mathrm{kat} / \mathrm{g}$, respectively, were obtained in culture supplemented with mixed carbon source of starch:glucose in ratio of (15:5) g/g. This clearly indicates that, the production of enzyme is induce with the presence of starch in culture. This results are also Further increase in glucose ratio beyond $5 \mathrm{~g} / \mathrm{L}$ in culture resulted in significant reduction in both specific and volumetric enzyme production. The lowest values of both specific and volumetric enzyme production were obtained in starch free culture. This repression effect of glucose on enzyme production in our study was also reported in other authors during $\alpha$-amylase production by B. subtilis [22-26-29]. 


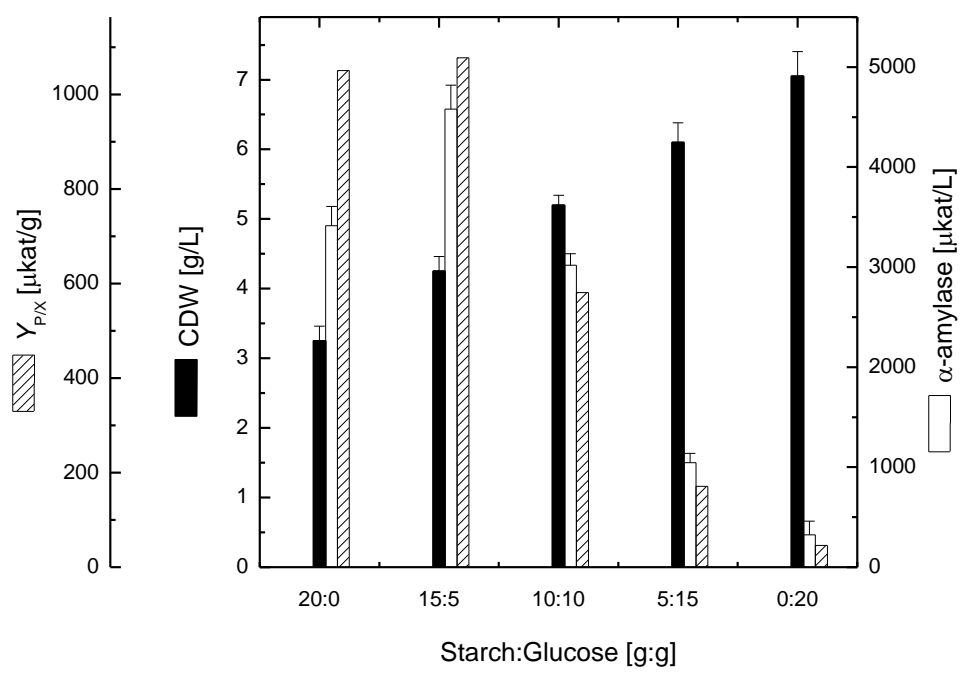

Figure 3. Effect of different starch:glucose ratio on cell growth and $\alpha$-amylase production during submerged fermentation of B. polymyxa. Data were taken after $20 \mathrm{~h}$ cultivation (Values are mean \pm standard deviation, $n=3$ )

\section{Kinetics of cell growth and $\alpha$-amylase production in optimized medium}

For better understating of the advantages of the new medium formula (which includes starch and glucose in ratio of $15: 5 \mathrm{~g} / \mathrm{g}$, in culture), cultivations were conducted in shake flask culture in batch mode. As shown in figure 4, cells grew exponential after inoculation without any observed lag phase as in medium of only starch as carbon source. In this culture, cells utilized the available sugar in culture (glucose) during the adaptation phase until starting amylase production. The growth rate of cells in this culture was $0.283 \mathrm{~g} / \mathrm{L} / \mathrm{h}$ and reached maximal biomass of $4.3 \mathrm{~g} / \mathrm{L}$ after only $16 \mathrm{~h}$ cultivation (about 4 hours less than the corresponding batch culture using only starch as substrate). During this phase, $\alpha$-amylase was produced continuously in culture by cells with production rate of $322 \mu \mathrm{kat} / \mathrm{L} / \mathrm{h}$ and reached the maximal value of $4550 \mu \mathrm{kat} / \mathrm{L}$ after $16 \mathrm{~h}$. This value was more than double of those obtained in initial medium which include starch as sole carbon source. On the other hand, the cell specific production was increased gradually by time and reached about $1060 \mu \mathrm{kat} / \mathrm{g}$ after 16 $\mathrm{h}$ when cells entered the stationary phase which is also the same of termination of enzyme production phase. Further increase in the value specific production was as a result of the decrease of biomass during the decline phase and not due to a real increase in cell productivity [27].
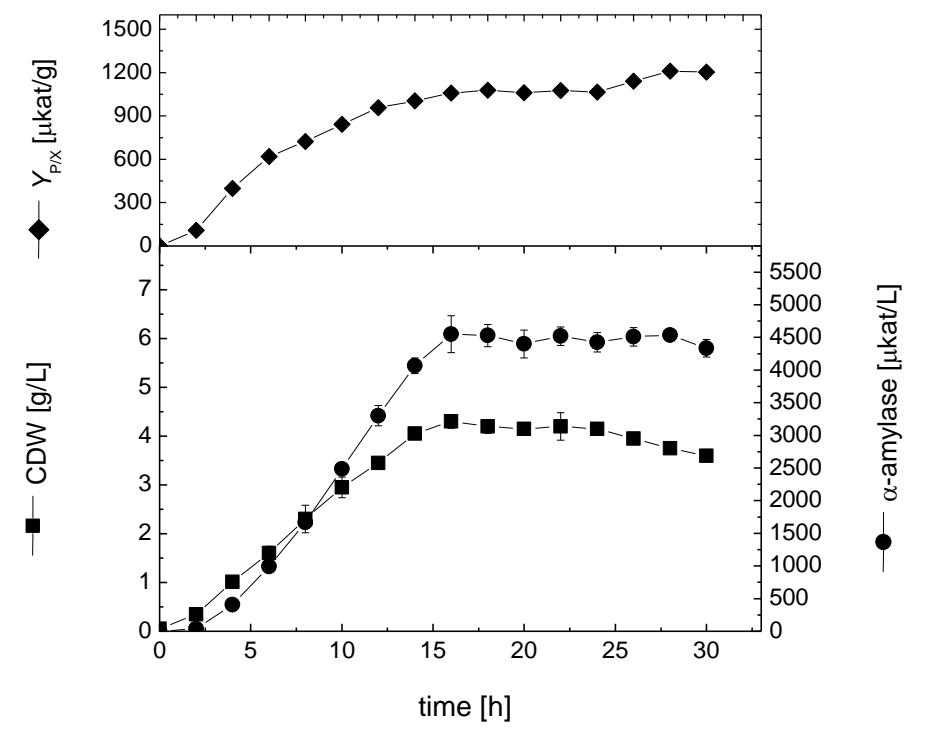

Figure 4. Time profiles of cell growth and $\alpha$-amylase production during submerged fermentation of $B$. polymyxa. In starch:glucoe medium in ratio of $15: 5[\mathrm{~g} / \mathrm{g}]$ in shake flask culture (Values are mean \pm standard deviation, $n=3$ ) 


\section{Production of $\alpha$-amylase in 2-L stirred tank bioreactor}

For better understanding of enzyme production kinetics and scalability of this process, cultivations were carried out in 3-L stirred tank bioreactor with working volume of 2-L, inoculum size, medium composition and other cultivation parameters were the same as in shake flask cultures. As shown in figure 5, cells grew exponentially without significant lag phase with rate of $0.425 \mathrm{~g} / \mathrm{L} / \mathrm{h}$ reaching stationary phase by biomass of about $4.7 \mathrm{~g} / \mathrm{L}$ after $12 \mathrm{~h}$. This time was shorter by 4 hours compared to the corresponding batch culture in shake flask. During this active growth phase, the DO in culture decreased gradually as a result of high oxygen consumption in culture and reached about $28 \%$ saturation after $12 \mathrm{~h}$ (the time of late exponential growth phase). As cells entered the stationary phase, the DO value increased again and reached about $80 \%$ at the end of cultivation time. However, in parallel to active cell growth $\alpha$-amylase was produced in culture without any significant lag phase with rate of $417 \mu \mathrm{kat} / \mathrm{L} / \mathrm{h}$ and reached the maximal volumetric production of about 5210 $\mu \mathrm{kat} / \mathrm{L}$ after only $14 \mathrm{~h}$ (compare to only $4550 \mu \mathrm{kat} / \mathrm{L}$ in case of shake flask culture after $16 \mathrm{~h}$ cultivation).

The higher cell growth and enzyme production when the process transferred from shake flask to bioreactor in our study is due to the fact that cultivations in stirred tank bioreactor provides better aeration and agitation compared to shake flask culture and thus increase cell performance and productivity of aerobic microorganisms during biosynthesis of different primary and secondary metabolites [23-25-28].

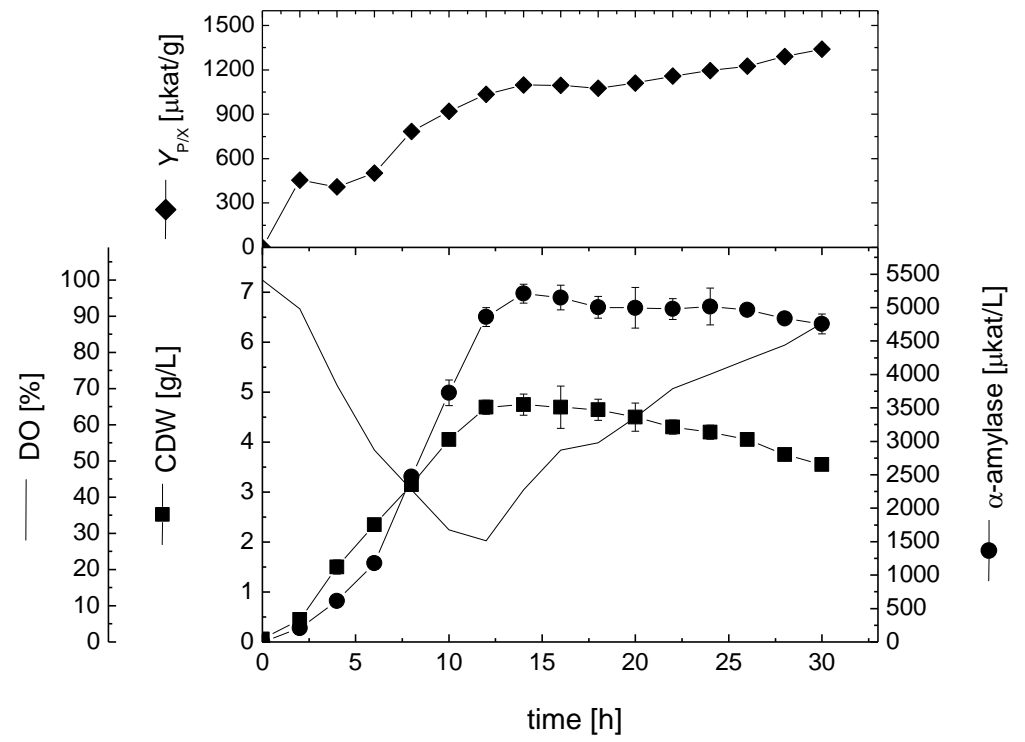

Figure 5. Time profiles of cell growth and $\alpha$-amylase production during submerged fermentation of $B$. polymyxa. Using optimized medium in 3-L stirred tank bioreactor (Values are mean \pm standard deviation, $n=3$ )

\section{Conclusion}

This study demonstrated clearly the high performance of the new isolated strain B. polymyxa which was isolated from sweet potato. The production process was first improved through the increase of starch concentration in culture from $10 \mathrm{~g} / \mathrm{L}$ to $20 \mathrm{~g} / \mathrm{L}$. Further improvement of this process was process by applying a mixed carbon source in form of starch:glucose in ratio (15:5), this not only resulted in an increase in enzyme production but also significant reduction of the production phase from $20 \mathrm{~h}$ to only $16 \mathrm{~h}$. By scaling up the process from shake flask to bioreactor level, the enzyme production was further increased and the production time was further shortened to only $12 \mathrm{~h}$. The obtained results in this work clearly demonstrate that the isolated strain in this study could serve as alternative biofactory for $\alpha$-amylase production in industrial scale.

\section{References}

[1] H El Enshasy, Y Abdel Fattah, and NZ Othman. Amylases: Characteristics, sources, production and applications. In:Yang S-T, El Enshasy HA, Thongchul N, (Eds) Bioprocessing Technologies in Biorefinery for Sustainable Production of Fuels, Chemicals, and Polymers, Wiley, USA (2013). in press.

[2] Alam S, Hong J and Weigand WA. Effect of yeast extract on $\alpha$-amylase synthesis by Bacillus amyloliquefaciens. Biotechnology Bioengineering 33, 1989, 780-785.

[3] MA Farid, HA El-Enshasy, and AM Noor El-Deen. Alcohol Production from Starch by Mixed Cultures of Aspergillus awamori and Immobilized Saccharomyces cerevisiae. Journal of Basic Microbiology. 42, 2002, 162-171.

[4] A Asgher, MJ Asad, SU Rahman, and RL Legge. A thermostable $\alpha$-amylase from moderately thermophilic Bacillus subtilis strain for starch processing. Journal of Food Engineering. 79, 2007, 950-955.

[5] OI Kubrak, JM Storey, KB Storey, VI Lushchak. Production and properties of $\alpha$-amylase from Bacillus sp. BKL20. Canadian Journal of Microbiology. 56, 2010, 279-288.

[6] Kandra, L. (2003). $\alpha$-amylase of medical and industrial importance. J. Mol. Structure (Theochem), 666-667: 487-498. 
[7] B Balkan and F Ertan F. Production and properties of $\alpha$-amylase from Penicillium chrysogenum and its application in starch hydrolysis. Prep. Biochemistry and Biotechnology. 35, 2005, 422-423.

[8] S Sivaramakrishnan, D Gangdharan, KM Nampoothiri, CR Soccol and A Pandey. A-amylases from microbial sources- An overview on recent developments. Food Technology and Biotechnology. 44, 2006, 173-184.

[9] MR Sarmidi, and HA El Enshasy. Biotechnology for Wellness Industry: Concepts and Biofactories. International Journal of Biotechnology for Wellness Industries. 1, 2012, 3-28.

[10] H El Enshasy, A Abuoul-Enein, S Helmy, and Y El Azaly. Optimization of The Industrial Production of Alkaline Protease By Bacillus licheniformis In Different Production Scales. Australian Journal of Basic and Applied Sciences. 2, $2008,583-593$.

[11] U Beshay, and H El-Enshasy. Production of $\alpha$-amylase by Bacillus amyloliquefaciens during batch cultivation in shake flask and stirred tank bioreactor. Deutsche Lebensmittel-Rundschau. 98, 2002, 5-9.

[12] H El Enshasy. Bioprocess development for the production of $\alpha$-amylase by Bacillus amyloliquefaciens in batch and fed-batch cultures. Journal of Microbiological Research. 7, 2007, 560-568.

[13] G Rajagopalan G, and C Krishnan. Optimization of medium and process parameters for a constitutive $\alpha$-amylase production from a catabolite derepressed Bacillus subtilis KCC 103. Journal of Chemical Technology and Biotechnology. 83, $2008,654-661$.

[14] N Samie, KA Noghabi, Z Gharegozloo, HS Zahiri, G Ahmadian, H Sharafi, R Behrozi, and H Vali H. Psychrophilic $\alpha$-amylase from Aeromonas veronii NS07 isolated from farm soils. Process Biochemistry 47, 2012, 1381-1387.

[15] NA Logan, and RCW Berkeley. Identification of Bacillus strains using the API system. Journal of General Microbiology 130, 1984, 1871-1882.

[16] B Stellmach. Determination of $\alpha$-amylase according to Bernfeld method. In: Stellmach B (Ed.). Determination methods for enzymes in pharmacy, food chemistry, technology, biology and medicine. Steinkopf Verlag, Darmstadt, 1988, pp: 29-31.

[17] K Florkin, and EH Stotz. Units of enzyme activity. Comprehensive Biotechnology, 30, 1973, 36-37.

[18] PHA Sneath. Endospore forming Gram-positive rods and cocci. In: Sneath, PHA (Ed), Bergey's Manual of Systematic Bacteriology Vol. 2. Williams\&Willkins, Baltimore, USA. 1984, pp 1104-1139.

[19] F Erem, M Certel, and B Karakas. Identification of Bacillus species isolated from ropey breads both with classical methods and API identification kits. Akeniz Üniversitesi Ziraat Fakültesi Dergisi 22, 2009, 201-210.

[20] DM Rothstein, PE Delvin, and RL Cate. Expression of $\alpha$-amylase in Bacillus licheniformis. Journal of Bacteriology, 168, 1986, 839824.

[21] AI Adeleye. Production and control of extracellular $\alpha$-amylase in Micrococcus varians. Jouranal of Basic Microbiology 30, 1990, 723-727.

[22] E Duran-Paramo, O Gracia-Kirchner, JF Harvagault, D Thomas, and JB Barbotin. A-amylase production by free and immobilized Bacillus subtilis. Applied Biochemistry and Biotechnology 84-86, 2000, 479-485.

[23] H El Enshasy, Y Abdel Fattah, A Atta, M Anwar, H Omar, S Abou El magd, and R Abou Zahra. Kinetics of cell growth and cyclosporine A production by Tolypocladium inflatum during process scaling up from shake flask to bioreactor. Journal of Microbiology and Biotechnology 18, 2008, 128-134.

[24] C Then, Z Othman, WA Wan Mustapha, MR Sarmidi, R Aziz, and HA El Enshasy. Production of alginate by Azotobacter vinelandii in semi-industrial scale using batch and fed-batch cultivation systems. Journal of Advanced Scientific Research, 3, 2012, 45-50.

[25] H El Enshasy, C Then, NZ Othman, H Al Homosany, M Sabry, MR Sarmidi, and RA Aziz, (2011). Enhanced xanthan production process in shake flasks and pilot scale bioreactors using industrial semi-defined medium. African Journal of Biotechnology, 10, 2011,1029-1038.

[26] Nagib A. Elmarzugi ; Guat, T.C; El Enshasy, H.A.Othman, N. Z, (2010) Optimization of Medium Composition and Biochemical Engineering Parameters for High Cell Mass Production of Nitrogen Fixing Bacteria Sinorhizobium Meliloti in Pilot Scale Levels. 3rd International Conference on Biotechnology for the Wellness Industry, October 08-10/2010, Kuala Lumpur - Malaysia.

[27] Elmarzugi, Nagib, Enshasy, H. E., Malek, R. A., Othman, Z., Sarmidi, M. R., and Aziz, R. A. (2010) Optimization of cell mass production of the probiotic strain Lactococcus Latis in batch and fed-batch culture in pilot scale levels, In Current research,technology and education topics in applied microbiology and microbial biotechnology (Vilas, A. M.-. Ed.),pp 873-879, Formatex, Medrid - Spain.

[28] Nagib A Elmarzugi, (2009) Overview on Modern Biotechnology, The proceedings of 5th National Biotechnology Conference, March 21, Sabratha, Libya.

[29] Nagib A. Elmarzugi, Wedad K. Esa, Hana R. Bahroon, Abdullah M. Jarari, Hatem F. Gharour, Rogia Amara, Sokiana alsaadawi, Naji Morset, Ibrahim Serti, Abdelmonaam Abolayeha, Asaad A. Omar, Mohamed M. Shreef, (2007) Production of Bio Membrane (Amnion Sheet) for Tissue Graft, (EJBMB),Vol. 25. 